\title{
Selected physicochemical and solubilization properties of pharmacopeal solutions of dry green tea leaf extract (Ext. Camellia sinensis L. folium aqu. siccum)
}

\author{
ZBIGNIEW MARCZYŃSKI ${ }^{1 *}$, BEATA SKIBSKA ${ }^{1}$, SŁAWOMIRA NOWAK², IZABELA RYCHLIŃSKA², \\ JERZY JAMBOR 3 , MARIAN MIKOŁAJ ZGODA ${ }^{4}$
}

${ }^{1}$ Department of Pharmacy, Chair of Applied Pharmacy

Faculty of Pharmacy

Medical University in Łódź

Muszyńskiego 1

90-151 Łódź, Poland

${ }^{2}$ Department of Pharmacognosy, Chair of Pharmacognosy

Faculty of Pharmacy

Medical University in Łódź

Muszyńskiego 1

90-151 Łódź, Poland

${ }^{3}$ Europlant Group Phytopharm Klęka S.A.

Klęka 1

63-040 Nowe Miasto n. Wartą, Poland

${ }^{4}$ Extramural Doctoral Studies

Chair of Applied Pharmacy,

Faculty of Pharmacy

Medical University in Łódź

Muszyńskiego 1

90-151 Łódź, Poland

* corresponding author: phone/fax:+4842 6779240, e-mail: zbigniew.marczynski@umed.lodz.pl

\section{Summary}

Introduction: Green tea offers not only pleasant, delicate flavor, but also provides health benefits. The extract contains, among others, polyphenols responsible for antioxidant and anti-inflammatory properties. 
They reduce the risk of cancer and their presence exerts preventive activity against cardiovascular diseases.

Objective: Analysis of selected physicochemical and solubilizing properties of pharmacopoeial-true solutions of dry green tea extract.

Methods: The caffeine content was determined in the extract and in dry residue after solubilization by high performance liquid chromatography. The process of micellar solubilization of cholesterol granules and ketoprofen was carried out in model solutions of green tea extract.

Results: The obtained results indicate that the prepared 'ex tempore' leaf green tea infusion subjected to short thermal exposure will be characterized by significant solubilization abilities.

Conclusions: The outcomes of the research pointed to the possibility of developing a solid oral dosage form with titrated dry green tea extract of expected pharmacotherapeutic profile.

Key words: Camellia sinensis, phytochemicals, solubilization, ketoprofen, caffeine, cholesterol

\section{INTRODUCTION}

Nowadays, selected classes of phytochemicals e.g. polyphenols such as flavonoids, proanthocyanidins, catechins including epigallocatechin gallate are used in the prevention of civilization diseases. They are administered in the form of extracts. As introduced into the periodic or daily diet, they reduce the risk of diseases or significantly slow down the course of those initiated by free radicals i.e. cancer and cardiovascular and neurodegenerative diseases [1-3].

Chromatographic methods (HLPC, UPLC, MSA, DAD) were applied to determine the content of fundamental classes of phytochemicals i.e. phenolic acids and their derivatives, catechins, xanthine alkaloids (purine), proanthocyanidins and flavonols, flavones and forms of $\mathrm{O}$-glycosides and their acetyl derivatives [4-9] in extracts from tea brands available in the market (green, white, pu erh), which decides on effective antioxidant and pharmacological activity [10,11].

Special attention should be paid to quantitative relation between levels of caffeine and catechins when the application profile of tea brands and their extracts is determined [12].

The studies on the solubility of phytochemicals contained in the dry green tea leaf extract (Ext. Camellia sinensis L. folium aqu. siccum) [13] were the inspiration for determining the physicochemical properties of aqueous solutions of the extract and, above all, for the determination of caffeine in exposure solutions after equilibrium solubilization in the medium of specific osmotic pressure of ketoprofen and granulometrically modified cholesterol $[14,15]$.

The obtained results enable to develop an oral solid dosage form containing dry green tea extract (Ext. Camellia sinensis L. aqu.siccum) of expected pharmacotherapeutic profile which takes into account (Lindblat index) the effective micellar or hydrotropic solubilization of lipophilic medicinal agents in the gastrointestinal tract [16].

\section{MATERIAL AND METHODS}

\section{Material}

Dry aqueous extract from green tea leaves: Extractum Camellia sinensis L. folium aqu. siccum (100\% native) - Europlant Group Phytopharm Klęka S.A., Poland; Koffein wasserfrei Pulver (caffeine anhydrous powder) - BASF, Pharma Chemikalien $\mathrm{GmbH}$ Co KG (Germany), Lot. 694661AX10.

Determination of caffeine content in extract and dry residues after solubilization was performed by high performance liquid chromatography (HPLC).

\section{Apparatus}

Hewlett-Packard liquid chromatograph 1100 series including 1311A pump, HP 1322A degasser, $20 \mu \mathrm{l}$ injector (Rheodyne 7725i, Cotati. CA, USA) and HP 1314A variable wavelength UV/VIS detector was used to determine the amount of caffeine in the dry green tea leaf extract and model dry residues by reverse phase high-performance liquid chromatography (RP-HPLC) method. The extracts were separated using MN (Macherey Nagiel) $(250 \times 4 \mathrm{~mm})$ column packed with Nucleodur C18 solid phase carrier of particle size $5 \mu \mathrm{m}$ with $4 \mathrm{x} 4 \mathrm{~mm}$ guard column (Hypersil ODS, $5 \mathrm{~mm}$, Germany). 


\section{Chromatographic procedure}

Extracts ( $\sim$ and dry residues after solubilization) were separated by gradient elution using solvents as follows: A: water - phosphoric acid (99.5:0.5) and $\mathrm{B}$ : methanol $(\mathrm{MeOH})$. Separation conditions: $0-10$ min: $25 \%$ B in A, $10-20$ min: $85 \%$ B in A, 2025 min: $25 \% \mathrm{~B}$ in $\mathrm{A}$. The separation was performed at room temperature at a flow rate of $1 \mathrm{ml} / \mathrm{min}$ and detection in UV light at $272 \mathrm{~nm}$ (sensitivity 0.05 AUFS). HPLC-grade solvents were used: methanol (Merck, Germany), ortophosphoric acid (Sigma Aldrich), redistilled water.

The reference substance - caffeine - was Caffein anhydrous powder (Koffein wasserfrei pulvis) from BASF, Germany. Identification of caffeine in the extract was performed by RP-HPLC method by comparing the retention time of the obtained signal with retention time of the reference substance.

The prepared extracts were injected into a column consecutively six times $(n=6)$ in the volume of $10 \mu \mathrm{l}$.

\section{Calibration of measurement system}

Caffeine standard solution $(0.0154 \mathrm{~g} / 50 \mathrm{ml})$ was prepared in $25 \% \mathrm{MeOH}$ and a final concentration of $0.308 \mathrm{mg} / \mathrm{ml}$ was obtained. Calibration curves for caffeine were prepared in a concentration range of $18.48-308 \mu \mathrm{g} / \mathrm{ml}$ for 6 declared concentrations. Calibration curves for caffeine are described by the equation:

$\mathrm{y}=9 \mathrm{E}+0.7 \mathrm{x}-65923$ at correlation coefficient $\mathrm{r}=0.9996$.

The results were expressed in $\mathrm{g} / 100 \mathrm{~g}$ of dry extract weight (\%).

\section{Viscosity and surface tension of model aqueous solutions of Ext. Camellia sinesis L. folium aqu. siccum}

The viscosity measurements of aqueous solutions of Ext. Camellia sinensis L. folium aqu. siccum in $0.1 \mathrm{~mol}$ $\mathrm{HCl}$ and in phosphate buffer of $\mathrm{pH}=6.88$ were performed according to the Polish Standard [16] using Ubbelohde viscosimeter. They were the basis for calculating from the equation

$$
[\eta], G L L=\frac{\left[n_{\mathrm{sp}}+3 \ln \left(\eta_{\mathrm{sol}} / \mathrm{n}_{\mathrm{oH}} \mathrm{O}\right)\right]}{4 \times c}
$$

calculating the limiting viscosity number $[\eta]$ as well as selected hydrodynamic values: $M_{\eta}, R_{o}, R_{\text {abs }}$ and $\Omega$ [17]. Critical micellar concentration ( $\mathrm{cmc}$ ) was calculated analogically to that of publication [17].

The surface tension of model aqueous solutions - $\gamma_{\text {sol. }}^{25}$ of Ext.Camellia sinensis L. folium aqu. siccum were determined by stalagmometric method acc. to the Polish Standard [17]. The numerical value of $\mathrm{cmc}\left(\mathrm{g} / 100 \mathrm{~cm}^{3} ; \mathrm{mol} / \mathrm{dm}^{3}\right)$ was the basis for calculating from the equation:

$$
\Delta \mathrm{G}_{\mathrm{m}}^{\mathrm{o}}=2.303 \mathrm{RT} \log \mathrm{cmc}
$$

the thermopotential for the formation of micelles $-\Delta \mathrm{G}_{\mathrm{m}}^{\mathrm{o}}$.

After substituting the physicochemical values and multiplying them as well as simplifying and converting to kJ, finally $\Delta \mathrm{G}_{\mathrm{m}}^{\mathrm{o}}$ was calculated from the equation:

$$
\Delta \mathrm{G}_{\mathrm{m}}^{\mathrm{o}}=5.709043 \cdot \log \mathrm{cmc}\left[\mathrm{kJ} / \mathrm{dm}^{3}\right]
$$

The value of the decrease of the surface tension coefficient in the critical area $-\gamma_{\mathrm{cmc}}^{25}$ was the basis for calculating from the equation -

$$
\mathrm{A}_{\mathrm{m}}=\frac{\mathrm{k} \cdot \mathrm{T}}{\mathrm{\gamma}_{\mathrm{sol} .}^{25}-\gamma_{\mathrm{cmc}}^{25}}
$$

the average area per one molecule of the surfactant $-\mathrm{A}_{\mathrm{m}}$ at phase boundary.

The above dependence results from dividing both sides of the equation of state of perfect areas $\pi \cdot A_{m} \cdot R \cdot T$ by Avogadro number (constant) leading to the equation

$$
\mathrm{f}(\pi) \cdot \mathrm{A}_{\mathrm{m}}=\mathrm{k} \cdot \mathrm{T}
$$

$$
\text { where } \mathrm{f}(\pi)=\gamma_{\mathrm{H}_{2} \mathrm{O}}-\gamma_{\mathrm{cmc}}^{25} \text {. }
$$

After substituting the physicochemical values to the above equation and then after multiplying and simplifying the following equation is obtained:

$$
\mathrm{A}_{\mathrm{m}}=\frac{411.6410 \cdot 10^{-20} \mathrm{~m}^{2}}{71,98 \cdot-\mathrm{\gamma}_{c m c}^{25}}
$$

\section{Micellar solubilization of cholesterol granules and ketoprofen in model solutions of Ext. Ca- mellia sinensis L. folium aqu. siccum}

The process of micellar solubilization was performed in a container of $\mathrm{V}=100 \mathrm{~cm}^{3}$ into which there were 
weighed not less than $450 \mathrm{~g}$ of homogeneous cholesterol granules of $\Phi=0.5 \mathrm{~mm}$, in the case of ketoprofen (technological form of lipophilic therapeutic agent) the weighed quantity did not exceed $0.400 \mathrm{~g}$.

After equilibrium solubilization of cholesterol and ketoprofen the solutions were prepared for viscosity $(\eta)$ and surface tension $\left(\gamma_{\text {sol. }}^{25}\right)$ measurements similarly to the patent publication [15].

Calculated basic viscosity and hydrodynamic values allowed to estimate in the equilibrium system from the equations:

$$
\mathrm{n}_{(\mathrm{s}, \mathrm{k})}=\frac{M_{\mathrm{\eta}} a d d \cdot-M_{\eta(s o l .)}}{254.3}
$$

and

$$
\mathrm{n}_{(\text {s, chol })}=\frac{M_{\eta} a d d \cdot-M_{\text {n(sol. })}}{386.64} .
$$

the numerical values of solubilization indices $\mathrm{n}_{(\mathrm{s}, \mathrm{k})}$ and $\mathrm{n}_{(\mathrm{s}, \mathrm{chol})}$ for ketoprofen and cholesterol.

The surface activity of the micelles at the phase boundary was estimated by calculating the $\mathrm{A}_{\mathrm{m}}$ coefficient for the exposure and saturated solutions after equilibrium solubilization of ketoprofen and cholesterol.

Ethical approval: The conducted research is not related to either human or animal use.

\section{RESULTS AND DISCUSSION}

The physicochemical properties of classes of phytochemicals contained in the green tea leaf extract (Ext. Camellia sinensis L. folium aqu. siccum) [13] have been the inspiration for conducting preformulation studies on the surface activity and solubilization capacities in equilibrium system in model solutions of acceptor fluids (water, $0.1 \mathrm{~mol} \mathrm{HCl}$, phosphate buffer of $\mathrm{pH}_{\left(\mathrm{a}_{\left.\mathrm{H}^{+}\right)}=6.88\right) \text {. }}$

It results from the basic viscosity and hydrodynamic values presented in table 1 that the complex solubilization process of lipophilic ketoprofen was most effective in aqueous solution, whereas in $0.1 \mathrm{~mol} \mathrm{HCl}$ and phosphate buffer solution of

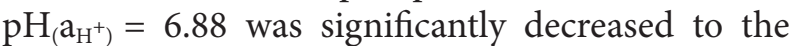
level of solubilization index $-\mathrm{n}_{(\mathrm{s}, \mathrm{k})} \leq 0.3(\mathrm{~mol} / \mathrm{mol})$.

Unexpectedly, the process of solubilization of cholesterol granulometric form (granule diameter $\Phi=0.50 \mathrm{~mm}$ ) was effective quantitatively in the aqueous solution of the extract and in the aqueous solution of $0.1 \mathrm{~mol} \mathrm{HCl}$ as evidenced by the calculated from the viscosimetric measurements - numerical values of the solubilization indices $\mathrm{n}_{(\mathrm{s}, \text { chol })}=2.8437$ and $2.3686(\mathrm{~mol} / \mathrm{mol})$.

The amount of solubilized cholesterol in phosphate buffer medium of $\mathrm{pH}_{\left(\mathrm{a}_{\mathrm{H}}^{+}\right)}=6.88$ decreased significantly by about $50 \%$. The obtained results of preformulation studies are presented in table 1.

The thermodynamic assessment of the solubilization capabilities of phytochemicals contained in the green tea leaf extract was performed by determining the critical micelle concentration $(\mathrm{cmc})$ and by calculating the thermodynamic potential for micelle formation $\left(\Delta \mathrm{G}_{\mathrm{m}}^{\circ}\right)$ as well as $\mathrm{A}_{\mathrm{m}}$ coefficient which determines the lipophilic stability and size of the lipophilic uplift of the micellar adduct above the phase boundary (tab. 2).

It results from table 2 that the significant application increase in the stability of the complex micellar adduct took place in case of solubilization of the granulometric form of cholesterol, as it was evidenced by the numerical value of $\Delta \mathrm{G}_{\mathrm{m}}^{\circ}$ from $-18.8094 \mathrm{~kJ}$ in phosphate buffer of $\mathrm{pH}_{\left(\mathrm{a}_{\mathrm{H}^{+}}\right)}=6.88$ (model duodenal contents - bile "A") to $-21.1219 \mathrm{~kJ}$ in $0.1 \mathrm{~mol} \mathrm{HCl}$ (model gastric juice). Also in the environment of the aqueous extract solution, the solubilization process is efficient and the stability of the adduct is determined by $\Delta \mathrm{G}_{\mathrm{m}}^{\mathrm{o}}=-19.9779 \mathrm{~kJ}$ (tab. 2).

The process of lipophilic ketoprofen solubilization is characterized by a stable value of $\Delta \mathrm{G}_{\mathrm{m}}^{\circ}$ in the range of $-17.5499 \mathrm{~kJ}$ for $0.1 \mathrm{~mol} \mathrm{HCl}$ to $-18.2731 \mathrm{~kJ}$ for the phosphate buffer of $\mathrm{pH}_{\left(\mathrm{a}^{+}\right)}=6.88$ at similar value $-18.1402 \mathrm{~kJ}$ for the aqueous extract (tab. 2).

The fact that the numerical value of $\mathrm{A}_{\mathrm{m}}$ coefficient for the micellar adduct is a value characteristic of itself for solubilized structure of ketoprofen (- regression of the $A_{m}$ value) and cholesterol (- deep variation of $\mathrm{A}_{\mathrm{m}}$ value due to $\mathrm{pH}_{\left(\mathrm{a}_{\mathrm{H}}{ }^{+}\right)}$and osmolarity of the model solution) is significant and characteristic for the thermodynamic course of the process of ketoprofen and cholesterol solubilization in model solutions of the extract.

This indicates that oral preparations containing dry extract of green tea leaves (Ext. Camellia sinensis L. folium aqu. siccum) significantly complement the lythogenolythic index in duodenal contents (bile "A") which is responsible for the process of lipophilic structure mass exchange on phase boundary - in the small intestine in the gastrointestinal tract $[19,20]$.

The physicochemical phenomenon that needs clarification is the active role of caffeine in the form of physicochemical structural interactions ( with sugar alcohols) in the process of solubilization of ketoprofen and cholesterol lipophilic structures [2124]. 
Table 1

Viscosity and hydrodynamic parameters of model solutions of green tea leaf dry extracts - Ext. Camellia sinensis L. folium aqu. siccum in water, in $0.1 \mathrm{~mol} \mathrm{HCl}$ and in phosphate buffer of $\mathrm{pH}_{(} \mathrm{a}_{\left.\mathrm{H}^{+}\right)}=6.88$ solubilizing in equilibrium conditions ketoproten and cholesterol

\begin{tabular}{|c|c|c|c|c|c|c|c|c|}
\hline $\begin{array}{l}\text { Exposure solutions Ext. Camellia } \\
\text { sinensis L. folium aqu. siccum }\end{array}$ & $c_{\text {exp }} g \cdot 100 \mathrm{~cm}^{3}$ & {$[\eta]$} & $M_{\eta}$ & $\mathrm{R}_{\mathrm{o}} \cdot 10^{-7} \mathrm{~cm}$ & $\mathrm{R}_{\mathrm{o}} \cdot 10^{-8} \mathrm{~cm}$ & $\Omega[\mathrm{cm}]^{3}$ & $\mathrm{n}_{\text {(IsIk) }}$ & $\mathrm{n}_{\text {(IsIchol) }}$ \\
\hline 1. Extract solution in water & & 0.0243432 & 235.22 & 1.1859 & 0.9682 & $0.9735 \cdot 10^{-23}$ & & \\
\hline 2. + ketoprofen & 1.5310 & 0.0479356 & 722.28 & 2.1605 & 1.7641 & $2.2903 \cdot 10^{-21}$ & 1.9152 & 2.8437 \\
\hline 3. + cholesterol & & 0.0694603 & 1334.72 & 3.0001 & 2.4495 & $6.1571 \cdot 10^{-21}$ & & \\
\hline 1. Extract solution in $0.1 \mathrm{~mol} \mathrm{HCl}$ & & 0.0454746 & 661.95 & 2.0620 & 1.6836 & $1.9991 \cdot 10^{-21}$ & & \\
\hline 2. + ketoprofen & 1.6750 & 0.0484475 & 735.09 & 2.1809 & 1.7801 & $2.3651 \cdot 10^{-21}$ & 0.2877 & 2.3686 \\
\hline 3. + cholesterol & & 0.0768450 & 1577.75 & 3.2808 & 2.6787 & $8.0519 \cdot 10^{-21}$ & & \\
\hline \multicolumn{9}{|c|}{ 1. Extract solution in phosphate buffer } \\
\hline of $\mathrm{pH}_{(} \mathrm{a}_{\mathrm{H}+)}=6.88$ & & 0.0486564 & 740.35 & 2.1892 & 1.7874 & $2.3923 \cdot 10^{-21}$ & & \\
\hline 2. + ketoprofen & 2.4450 & 0.0510619 & 817.58 & 2.3085 & 1.8848 & $2.8051 \cdot 10^{-21}$ & 0.3036 & 1.2456 \\
\hline 3. + cholesterol & & 0.0658549 & 1221.08 & 2.8619 & 2.3366 & $5.3444 \cdot 10^{-21}$ & & \\
\hline
\end{tabular}

Table 2

Surface activity of model solutions of green tea leaf dry extracts - Ext. Camellia sinensis L. folium aqu. siccum with thermodynamic evaluation of solubilization capacity in relation to lipophilic structures of ketoprofen and cholesterol

\begin{tabular}{|c|c|c|c|c|c|c|}
\hline $\begin{array}{l}\text { Exposure solutions Ext. Camellia sinensis } \\
\text { L. folium aqu. siccum }\end{array}$ & $\begin{array}{c}\mathrm{c}_{\exp } \\
{\left[\mathrm{g} \cdot 100 \mathrm{~cm}^{3}\right]}\end{array}$ & $\begin{array}{c}\mathrm{cmc} \\
{[\mathrm{g} \cdot 100 \mathrm{~cm} 3]}\end{array}$ & $\begin{array}{c}\mathrm{cmc} \\
{\left[\mathrm{mol} / \mathrm{dm}^{3}\right]}\end{array}$ & $\begin{array}{c}\Delta \mathrm{G}_{\mathrm{m}}^{\mathrm{o}} \\
{\left[\mathrm{kJ} / \mathrm{dm}^{3}\right]}\end{array}$ & $\begin{array}{c}\gamma_{\mathrm{cmc}}^{25} \\
{\left[\mathrm{~mJ} \cdot \mathrm{m}^{2}\right]}\end{array}$ & $\begin{array}{c}\mathrm{A}_{\mathrm{m}} \cdot 10^{-20} \\
{\left[\mathrm{~m}^{2}\right]}\end{array}$ \\
\hline 1. Extract solution in water & & 0.720 & $3.0612 \cdot 10-3$ & -14.3533 & 68.5 & 118.2876 \\
\hline 2. + ketoprofen & 1.5310 & 0.480 & $6.6456 \cdot 10-4$ & -18.1402 & 69.5 & 165.9842 \\
\hline 3. + cholesterol & & 0.420 & $3.1467 \cdot 10-4$ & -19.9779 & 68.0 & 103.4273 \\
\hline 1. Extract solution in $0.1 \mathrm{~mol} \mathrm{HCl}$ & & 0.420 & $6.3451 \cdot 10-4$ & -18.2550 & 70.5 & 278.1358 \\
\hline 2. + ketoprofen & 1.6750 & 0.620 & $8.4342 \cdot 10-4$ & -17.5499 & 68.5 & 118.2876 \\
\hline 3. + cholesterol & & 0.305 & $1.9965 \cdot 10-4$ & -21.1219 & 71.5 & 857.5824 \\
\hline \multicolumn{7}{|l|}{ 1. Extract solution in phosphate buffer of } \\
\hline $\mathrm{pH}_{(} \mathrm{a}_{\mathrm{H}+)}=6.88$ & & 0.480 & $6.4834 \cdot 10-4$ & -18.2015 & 70.5 & 278.1358 \\
\hline 2. + ketoprofen & 2.4450 & 0.515 & $6.2991 \cdot 10-4$ & -18.2731 & 65.5 & 63.5248 \\
\hline 3. + cholesterol & & 0.620 & $5.0737 \cdot 10-4$ & -18.8094 & 66.0 & 68.8362 \\
\hline
\end{tabular}

Table 3

The determined caffeine content in model solutions of green tea leaf dry extracts - Ext. Camellia sinensis L. folium aqu. siccum and equilibrium process of solubilization of ketoprofen and cholesterol

\begin{tabular}{|c|c|c|c|c|c|}
\hline $\begin{array}{l}\text { Exposure solutions of Ext. Camellia } \\
\text { sinensis L. folium aqu. siccum - dry } \\
\text { residue }\end{array}$ & Weight of the test portion in ' $\mathrm{g}$ '-range & Determined content [\%] & $\begin{array}{c}x[\%] \\
\text { for } n=6\end{array}$ & $\mathrm{SD}^{1)}$ & $\mathrm{RSD}^{2)}$ \\
\hline $\begin{array}{l}\text { 1. Green tea leaf dry aqueous extract } \\
\text { - Ext. Camellia sinensis L. folium } \\
\text { aqu. siccum }\end{array}$ & $0.0127-0.0128$ & $10.29-10.70$ & 10.47 & 0.1707 & 1.63 \\
\hline 2. Dry extract residue in water & $0.0124-0.0128$ & $6.48-7.16$ & 6.82 & 0.3276 & 4.81 \\
\hline + ketoprofen & $0.0132-0.0128$ & $6.86-7.05$ & 6.97 & 0.1061 & 1.52 \\
\hline+ cholesterol & $0.0124-0.0130$ & $7.25-7.46$ & 7.43 & 0.0943 & 1.27 \\
\hline 3. Dry extract residue in $0.1 \mathrm{~mol} \mathrm{HCl}$ & $0.0123-0.0127$ & $6.20-6.44$ & 6.29 & 0.1445 & 2.30 \\
\hline+ ketoprofen & $0.0126-0.0130$ & $4.40-6.29$ & 5.61 & 0.5052 & 9.01 \\
\hline+ cholesterol & $0.0123-0.0130$ & $5.32-5.52$ & 5.41 & 0.0942 & 1.74 \\
\hline \multicolumn{6}{|l|}{ 4. Dry extract residue in phosphate } \\
\hline buffer of $\mathrm{pH}_{(}\left(\mathrm{a}_{\left.\mathrm{H}^{+}\right)}=6.88\right.$ & $0.0125-0.0125$ & $5.47-5.52$ & 5.44 & 0.0537 & 0.99 \\
\hline + ketoprofen & $0.0125-0.0128$ & $4.20-4.32$ & 4.29 & 0.1022 & 2.38 \\
\hline+ cholesterol & $0.0124-0.0130$ & $4.69-4.93$ & 4.78 & 0.1769 & 3.70 \\
\hline
\end{tabular}

1) - standard deviation;

2) - relative standard deviation 
It results from the analytical data demonstrated in table 3 that during the preparation of model solutions for pre-formulation tests there comes to the hydrolysis of thermodynamic and hydrotropic bonds of caffeine which is observed as a decrease in the concentration in the exposure solution and at the same time as a significant regression in the numerical value of the solubilization index of ketoprofen and cholesterol $\left(-\mathrm{n}_{(\mathrm{Is}, \mathrm{k})} \mid\right.$ and $\left.\mathrm{n}_{(\mathrm{Is}, \mathrm{chol})}\right)$, (tab. 3) in model acceptor fluids in relation to the aqueous solution.

The obtained results indicate that green tea leaf infusion prepared 'ex tempore', subjected to short thermal exposure, will be characterized by - as confirmed by literature data [1-6] - significant solubilization capacity owing to the presence of glycosidic and hydrotropic caffeine bonds in the extract.

\section{CONCLUSIONS}

1. The obtained results demonstrate that in the dry aqueous extract from green tea leaves (Ext. Camellia sinensis L. folium aqu. siccum) - despite technological procedures including high temperature of drying process, there were preserved in significant content hydrotropic bonds of caffeine and other ligands, the presence of which determines solubility capacity and the order of basic viscosity $\left([\eta], M_{n}\right)$ and thermodynamic values $\left(R_{o}, R_{o b s}, \Omega\right)$. They allow calculating solubilization indices for model lipophilic structures of ketoprofen and cholesterol.

2. Quantitative course of the complex solubilization process in the environment of model exposure solutions of the extract solutions in water, $0.1 \mathrm{~mol}$ $\mathrm{HCl}$ and phosphate buffer of $\mathrm{pH}_{\left(\mathrm{a}^{+}\right)}=6.88$ indicates a significant quantitative decrease of the process, particularly in the pharmacopoeial acceptor fluid corresponding to the duodenal contents (bile "A"). This indicates hydrolysis-induced qualitative changes in the composition of phytochemicals that are responsible for micellar and hydrotropic solubilization, as indicated by the calculated values of indices - $\mathrm{n}_{(\mathrm{Is}, \mathrm{k})} \mid$ and $\mathrm{n}_{(\mathrm{Is}, \mathrm{sol})} \mid$ presented in table 2 .

3. Surface activity $\left(\gamma_{\text {sol. }}^{25}\right)$ and, above all, the calculated thermodynamic potential of micelle formation $-\Delta \mathrm{G}_{\mathrm{m}}^{\mathrm{o}}$ and the numerical value of $\mathrm{Am}$ coefficient (tab. 2) indicate a significant thermo- dynamic stability of the adduct with cholesterol and ketoprofen, despite observed regression of its value. This in the application option translates into the appropriate pharmacological profile of the solid oral dosage form (and/or dietary supplement) with proper dose of green tea leaf titrated dry aqueous extract (Ext. Camellia sinensis L. folium aqu. siccum).

4. The caffeine content in green tea leaf dry aqueous extract determined by HPLC method indicates a significant contribution of hydrotropic bonds of caffeine in the complex (adduct caffeine from fitochemical-organic ligands) process of solubilization of ketoprofen and cholesterol (granulometric form of $\Phi=0.5 \mathrm{~mm}$ in model acceptor fluids (water, $0.1 \mathrm{~mol} \mathrm{HCl}$, phosphate buffer of $\left.\mathrm{pH}_{\left(\mathrm{H}^{+}\right)}=6.88\right)$. The determined caffeine content in the dry residue after the equilibrium solubilization process indicates the progressive hydrolysis of the glycosidic bonds as evidenced by a significant decrease of its content in a dry residue after exposure to $0.1 \mathrm{~mol} \mathrm{HCl}$ and phosphate buffer of $\mathrm{pH}_{\left(\mathrm{a}_{\mathrm{H}^{+}}\right)}=6.88$. The above also indicates a significant contribution of caffeine glycosidic bonds to surface activity of dry aqueous extract in model acceptor solutions and quantitatively effective complex process of solubilization of ketoprofen and cholesterol from the surface of grain of $\Phi=0.5 \mathrm{~mm}$ [22].2].

\section{ACNOWLEDGEMENT}

The study was financed from the statutory subject of the Medicinal University in Łódż No. 503/3-02101/503-31-001.

Conflict of interest: Authors declare no conflict of interest.

\section{REFERENCES}

1. Majewski G, Lubecka-Pietruszewska K, KaufmanSzymczyk A, Fabianowska-Majewska K. Anticancer properties of selected plant polyphenols from the group of flavonoid and stilbenes. $\mathrm{Zdr}$ Publ 2012; 122(4):434-439. doi: http://dx.doi.org/ 10.12923/j.0044-2011/122-4/a.19

2. Stefańska B, Karlic H, Vargo F, Fabianowska-Ma- 
jewska K, Haslberger A. Epigenetic mechanisms in anticancer actions of bioactive food components - the implications in cancer prevention. Br J Pharmacol 2012; 167:279-297. doi: http:// dx.doi.org/10.1111/j.1476-5381.2012.02002.x

3. Ullah MF, Khan MW. Food as medicine: potential therapeutic tendencies of plant derived polyphenolic compounds. Asian Pac J Cancer Prev 2008; 9(2):187-95.

4. Anesini C, Ferraro GE, Filip R. Total polyphenol content and antioxidant capacity of commercially available tea (Camellia sinensis) in Argentina. J Agric Food Chem 2008; 56:9225-9229. doi: http://dx.doi.org/10.1021/jf8022782

5. Zhao Y, Chen P, Lin L, Harnly JM, Yu L, Li Zh. Tentative identification, quantitation and principal component analysis of green, pu-erh, green, and white teas using UPLC/DAD/MS. Food Chem 2011; 126:1269-1279. doi: http://dx.doi. org/10.1016/j.foodchem.2010.11.055

6. Pereira VP, Knor FJ, Vellasa JCR, Beltrame FL. Determination of phenolic compounds and antioxidant activity of green, black and white teas of Camellia sinensis (L.), Kuntze, Theacene. Rev Bras Plant Med 2014; 16(3):490-498. doi: http:// dx.doi.org/10.1590/1983-084X/13_061

7. El-Shahawi MS, Hamza A, Bahaffi SO, AlSibaai AA, Abduljabbar TN. Analysis of some selected catechins and caffeine in green tea by high performance liquid chromatography. Food Chem 2012; 134:2268-2275. doi: http://dx.doi. org/10.1016/ j.foodchem.2012.03.039

8. Scoparo CT, de Souza LM, Dartora M, Sassaki GL, Gorin PA. Lacomini M. Analysis of Camellia sinensis green and black teas via ultra high performance liquid chromatography assisted by liquid-liquid partition and two-dimensional liquid chromatography (size exclusion $\mathrm{x}$ reversed phase). J Chroamtogr A 2012; 1222:29-37. doi: http://dx.doi.org/10.1016/j.chroma.2011.11.038

9. Roman MC, Hildreth J, Bannister S. Determination of catechins and caffeine in Camillia sinensis raw materials, extracts and dietary supplements by HPLC-UV; single-laboratory validation. J AOAC Int 2013; 96(5):933-941.
10. Koszowska A, Dittfeld A, Puzon-Bronczyk A, Nowak J, Zubelewicz-Szkodzińska B. Polifenole w profilaktyce chorób cywilizacyjnych. Post Fitoter 2013; 4:263-266.

11. Saxena M, Saxena J, Nema R, Singh D, Gupta A. Phytochemistry of medicinal plants. J Pharmacogn Phytochem 2013; 1(6):168-182.

12. Fernandez PL, Martin MJ, Gonzalez AG, Pablos F. HPLC determination of catechins and caffeine in tea. Differentiation of green, black and instant teas. Analyst 2000; 125(3):421-425.

13. Marczyński Z, Skibska B, Nowak S, Jambor J, Zgoda MM. Actual solubility $\left(\mathrm{S}_{\text {|real. }}\right)$, level of hydrophilic-lipophilic balance $\left(\mathrm{HLB}_{\text {Requ. }}, \mathrm{HLB}_{\mathrm{D}}, \mathrm{HLB}_{\mathrm{G}}\right)$ and partition coefficient $(\log \mathrm{P})$ of phytochemicals contained in Ext. Camellia sinensis L. aqu. siccum in the light of general Hildebrand-Scatchard-Fedors theory of solubility Herba Pol 2018; 64(2):46-59. doi: http://dx.doi.org/10.2478/hepo-2018-0009.

14. Marczyński Z, Nowak S, Jambor J, Zgoda MM. Solubility and solubilizing capabilities of aqueous solutions of Extractum Taraxaci e radix cum herba aqu. siccum in light of selected values of general Hildebrand-Scatchard-Fedors theory of solubility. Herba Pol 2016; 62(4):66-81. doi: http://dx.doi.org/10.1515/hepo-2016-0022

15. Kosno J, Lukasek M, Fischer R, Zgoda MM, Nachajski M, Kołodziejczyk M. Sposób solubilizacji cholesterolu. Biuletyn Urzędu Patentowego 2016; 14(1109), 8(410769). Patentu udzielono 12.09.2017 r., Urząd Patentowy Rzeczpospolitej Polskiej Departament Badań Patentowych (DP.P.410769.9.Inog).

16. Polska Norma - PN-93/C-89430. Tworzywa sztuczne. Zasady normalizacji metod oznaczania liczby lepkościowej i granicznej liczby lepkościowej polimerów w roztworach rozcieńczonych (Dz. Norm i Miar 1993, Nr 3, poz. 5).

17. Zgoda MM, Nachajski MJ, Kołodziejczak MK, Woskowicz MH, Lukosek M. Solubilizacyjne właściwości nowych związków powierzchniowo czynnych (ZPC) produktów selektywnego oksyetylenowania kwasu cholowego. Część I. Polim Med 2007: T. XXXVII; 4:21-38. 
18. Polska Norma - PN-90/C-04809. Środki powierzchniowo czynne. Oznaczenie napięcia powierzchniowego $\left(\gamma_{\mathrm{s}}\right)$ i napięcia powierzchniowego $\left(\gamma_{i}^{25}\right)$. Dz Norm i Miar 1991, Nr 2, poz. A.

19. Zgoda MM, Karczewski T. Właściwości makrocząsteczek w płynach ustrojowych górnego odcinka przewodu pokarmowego. Część II. Diagn Lab 1993; 29:163-171.

20. Zgoda MM, Karczewski T. Tenzydy z grupy kopolimerów tlenku propylenu i tlenku etylenu. VII. Próba wykorzystania krytycznego stężenia micelarnego (cmc), poziomu równowagi hydrofilo-lipofilowej (HLB) oraz wymiarów makrocząsteczek (Ro, $\Omega$ ) w żółci „A” zdrowych i chorych do oceny właściwości litogenolitycznych polieterodioli. Acta Pol Pharm Drug Res 1990; 47(5-6):61-70.

21. Tavagnacco L, Schnupf U, Mason Ph. E, Saboungi M L, Cesaro A, Brady JW. Molecular dynamics simulation studies of caffeine aggregation in aqueous solution. J Phys Chem B
2011; 115(37):10957-10966. doi: http://dx.doi. org/10.1021/ jp2021352

22. Tavagnacco L, Engström O, Schnupf U, Saboungi M L, Himmel M, Widmalm G, Cesaro A, Brady JW. Caffeine and sugars interact in aqueous solutions: a simulation and NMR study. J Phys Chem B 2012; 116(38):11701-11711. doi: http://dx.doi.org/10.1021/jp303910u

23. Tavagnacco L, Brady JW, Cesaro A. The Interaction of sorbitol with caffeine in aqueous solution. Food Biophysics 2013; 8(3):216-222. doi: http://dx.doi.org/ 10.1007/s11483-013-9290-7

24. Tavagnacco L, Fonzo S Di, D’Amico F, Masciovecchio C, Brady JW, Cesaro A. Stacking of purines in water: the role of dipolar interactions in caffeine. Phys Chem Chem Phys 2016, 18:13478-13486. doi: http://dx.doi.org/10.1039/ C5CP07326J

\title{
Wybrane właściwości fizykochemiczne i solubilizacyjne farmakopealnych roztworów rzeczywistych suchego ekstraktu z liści zielonej herbaty (Ext. Camellia sinensis L. folium aqu. siccum)
}

\author{
ZBIGNIEW MARCZYŃSKI ${ }^{\circledR}$, BEATA SKIBSKA ${ }^{1}$, SŁAWOMIRA NOWAK², IZABELA RYCHLIŃSKA², \\ JERZY JAMBOR ${ }^{3}$, MARIAN MIKOŁAJ ZGODA ${ }^{4}$
}

\author{
${ }^{1}$ Zakład Farmacji Aptecznej, Katedra Farmacji Stosowanej \\ Wydział Farmaceutyczny \\ Uniwersytet Medyczny w Łodzi \\ ul. Muszyńskiego 1 \\ 90-151 Łódź \\ ${ }^{2}$ Zakład Farmakognozji, Katedra Farmakognozji \\ Wydział Farmaceutyczny \\ Uniwersytet Medyczny w Łodzi \\ ul. Muszyńskiego 1 \\ 90-151 Łódź
}


${ }^{3}$ Europlant Group Phytopharm Klęka S.A.

Klęka 1

63-040 Nowe Miasto n.Wartą

${ }^{4}$ Niestacjonarne Studium Doktoranckie

Katedra Farmacji Stosowanej

Wydział Farmaceutyczny

Uniwersytet Medyczny w Łodzi

ul. Muszyńskiego 1

90-151 Łódź

*autor, do którego należy kierować korespondencję: tel./fax: +48 4267792 40, email: zbigniew.marczynski@umed. lodz.pl

\section{Streszczenie}

Wstęp: Zielona herbata nie tylko niesie ze sobą przyjemny, delikatny smak po sporządzeniu naparu, ale również korzyści zdrowotne. Ekstrakt zawiera między innymi polifenole odpowiedzialne za właściwości antyoksydacyjne i przeciwzapalne. Zmniejszają one ryzyko wystąpienia nowotworów, a także ich obecność działa profilaktycznie w przypadku wystąpienia schorzeń układu krążenia.

Cel: Analiza wybranych właściwości fizykochemicznych i solubilizacyjnych farmakopealnych roztworów rzeczywistych suchego ekstraktu z zielone herbaty.

Metody: Oznaczono zawartość kofeiny w ekstrakcie i w suchych pozostałościach po solubilizacji metodą wysokosprawnej chromatografii cieczowej. Proces micelarnej solubilizacji granulatu cholesterolu i ketoprofenu przeprowadzono w modelowych roztworach ekstraktu z zielonej herbaty.

Wyniki: Uzyskane rezultaty wskazują, że przygotowany „ex tempore” napar z liści zielonej herbaty poddany krótkiej ekspozycji termicznej będzie charakteryzował się znaczącymi zdolnościami solubilizacyjnymi.

Wnioski: Otrzymane wyniki umożliwiają opracowanie stałej doustnej postaci leku z mianowanym suchym ekstraktem z zielonej herbaty o oczekiwanym profilu farmakoterapeutycznym.

\section{Słowa kluczowe: Camellia sinensis, fitozwiązki, solubilizacja, ketoprofen, kofeina, cholesterol}

